\title{
EVAUlating THE MOVEMENT PATTERNS OF SNAKE RIVER FINESPOTTED CUTTHROAT TROUT IN THE SNAKE RIVER BELOW JACKSON LAKE DAM, Grand Teton NaTional PARK
}

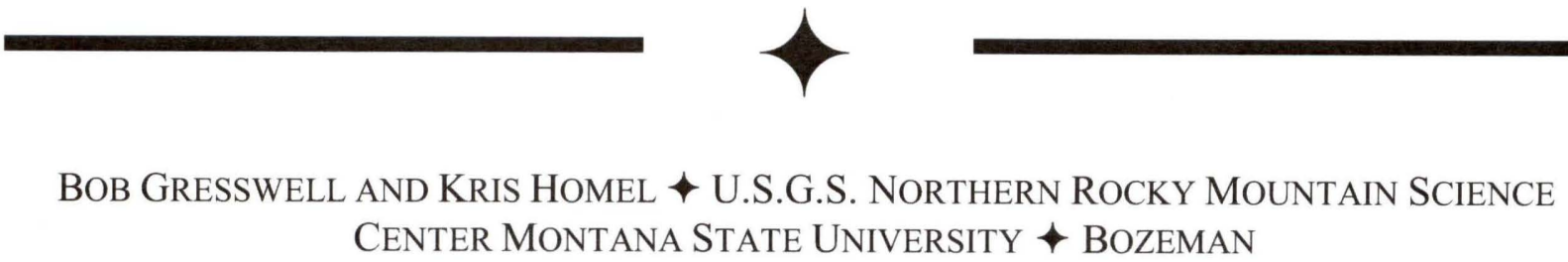

\section{$\downarrow$ AbSTRACT}

The Snake River finespotted cutthroat trout Oncorhynchus clarkii behnkei has been formally recognized as a subspecies of cutthroat trout Oncorhynchus clarkii, but it is more generally perceived as a morphologically divergent ecotype of the more broadly distributed Yellowstone cutthroat trout Oncorhynchus clarkii bouvieri. This large-river cutthroat trout has persisted in the Snake River downstream of Jackson Lake Dam through a century of flow regulation. Although there is a popular sport fishery focused on this native trout, spawning and distribution patterns throughout its range are poorly understood. Consequently, it is difficult to predict how future disturbances (e.g., climate change or an increase in the prevalence of nonnative species) may affect behavior or persistence. In 2008, radio telemetry techniques were used to identify spawning patterns of cutthroat trout. From August-October, 2007, 49 radio telemetry tags were implanted into cutthroat trout in the Snake River, Grand Teton National Park and fish movements were tracked during the spawning season. Significant temporal and spatial variability in spawning behavior was observed $(\mathrm{n}=22$ fish with distinct spawning migrations). The earliest spawning migration began at the end of April, and the last spawning migration was initiated in mid-July. Spawning was observed in the mainstem and side channels of the Snake River, several tributaries, and three major spring creek complexes. Although the majority of this spawning activity occurred within $40 \mathrm{~km}$ of the respective original tagging location, three fish migrated to spawning areas 75-100 river kilometers away. Ultimately, developing a comprehensive understanding of the behavioral variability of Snake River finespotted cutthroat trout and the habitat connectivity required to complete the life cycle will provide new insights into the management of this portion of the Snake River.

\section{$\uparrow \quad$ INTRODUCTION}

Little is known about the physical or biological variables that structure seasonal distribution patterns of cutthroat trout, particularly in large streams. Previous research suggests that physical habitat influences fish distribution across stream sizes (or fluvial geomorphic properties associated with that stream size). For example, Torgersen et al. (2006) evaluated the spatial structure of stream fish assemblages at different scales in three small rivers in Oregon and found that the relative importance of various physical attributes in explaining assemblage distribution patterns was scale dependent; at smaller scales, channel morphology exhibited a stronger influence on those patterns and at larger scales, temperature zones were a dominant explanatory variable. Other studies conducted in small rivers at the reach or channel-unit scale have identified associations between fish distribution and complex habitat (Pearsons et al. 1992), pool attributes (Harig and Fausch 2002), and thermal refugia (Torgersen et al. 1999).

In the absence of peer-reviewed literature regarding fish distribution patterns in large rivers, 
several conceptual frameworks provide some guidance. Vannote et al. (1980) proposed the River Continuum Concept to describe longitudinal distribution patterns of stream biota in relation to a continuous gradient of physical variables that correspond to changes in stream order and the biogeochemical processes associated with stream order. The River Continuum Concept was later expanded to include effects of serial discontinuities (e.g., dams) in the stream (Serial Discontinuity Concept; Ward and Stanford 1983) and different geomorphic processes in influencing patterns of distribution (Process Domains; Montgomery 1999). Tributary junctions may also function as discontinuities and have been described as potential biotic hotspots (Benda et al. 2004: Torgersen et al. 2008). These conceptual frameworks describe general physical processes that may structure fish distribution, but they do not deal with scale-dependent physical variables that could inform our understanding of how fish distribution is structured among streams.

The upper Snake River below Jackson Lake Dam, Grand Teton National Park, provides a unique opportunity to evaluate the distribution and behavioral patterns of a native salmonid, the Snake River finespotted cutthroat trout Oncorhynchus clarkii behnkei, in a large, regulated river. Jackson Lake Dam was constructed on the Snake River in 1905 and initially managed to provide irrigation water for agriculture interests in Idaho. From 1916-1957, the peak of the spring flood was generally delayed by 2 months, and no water was released October 1 - March 30 .

Following the construction of Palisades Dam in 1958, management of Jackson Lake Dam changed, and minimum winter flows were obtained. In addition, the spring peak of discharge occurred concurrently with tributary run-off, but above-average discharge was released throughout the summer until October 1 (Figure 1). Despite this shift in management, there is still considerable interannual variation in the discharge regime (i.e., timing, magnitude, frequency, duration, and rate-of-change) released from Jackson Lake Dam.

Although Snake River finespotted cutthroat trout have persisted in the Snake River downstream of Jackson Lake Dam through a century of flow regulation, the influence of the altered environment on cutthroat trout behavioral patterns remains unknown. This native cutthroat trout is endemic to the upper Snake River and has been formally recognized as a subspecies of cutthroat trout Oncorhynchus clarkii, but it is more generally perceived as a morphologically

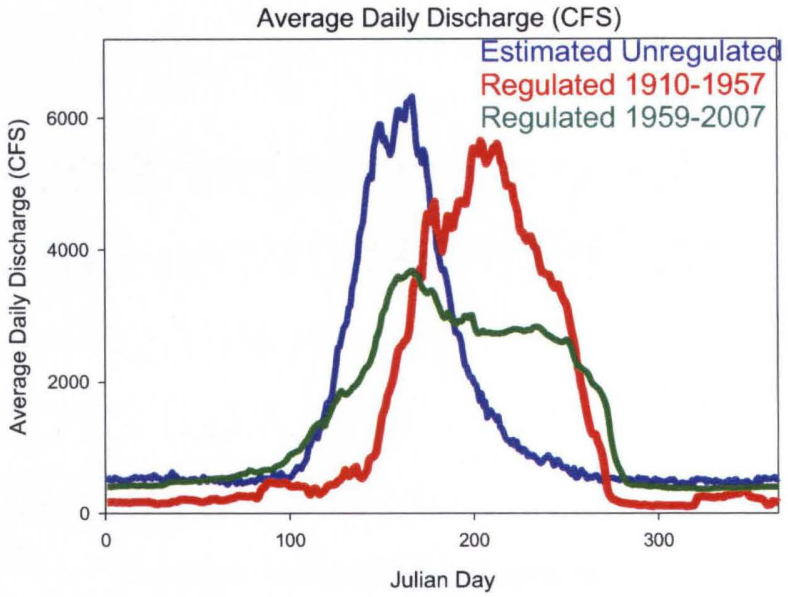

Figure 1. Average annual discharge records at the USGS gauge (Moran, Wyoming) located immediately below Jackson Lake Dam for the periods of time 1906-1957 (prior to the construction of Palisades Dam), 1959-2008 (beginning after full pool was reached in Palisades Reservoir), and the average annual estimated unregulated discharge that would be released from Jackson Lake in the absence of Jackson Lake Dam (prepared by the Bureau of Reclamation).

divergent (but not genetically distinct) ecotype of the more broadly distributed Yellowstone cutthroat trout Oncorhynchus clarkii bouvieri (Loudenslager and Kitchin 1979; Novak et al. 2005). Kiefling (1978) summarized initial research on Snake River finespotted cutthroat trout including spawning characteristics in several tributaries and spring creeks and population abundance and structure. Since then, there have been few published studies on Snake River finespotted cutthroat trout. Furthermore, information concerning the spawning and distribution patterns of the subspecies is incomplete, and it is difficult to predict how future disturbances (e.g., climate change or an increase in the prevalence of non-native species) would affect the behavior or survival of the native trout.

To better understand the life history organization of Snake River finespotted cutthroat trout, the overall objectives of our research were to identify movement patterns associated with spawning and the post-spawning distribution patterns. In 2008, radio telemetry was used to monitor the movements of 49 cutthroat trout during the spawning season from MarchJuly. Given the variability in movement we observed, an additional 199 radio tags were implanted in cutthroat trout in September and October 2008. The results from the 2008 tracking are presented here. 


\section{METHODS}

\section{Fish Capture and Radio Tagging}

Snake River finespotted cutthroat trout were captured via angling, raft-electrofishing, and backpack electrofishing from August-October, 2007 in the Snake River between Jackson Lake Dam and Moose Junction. Four sizes of radio tags (Lotek Wireless MCFT series: 3EM, 3FM, 3A, 3L; MHz frequencies: 164.200, $164.280,164.400,164.560$ ) were used in this study so that the ratio of the tag weight to the fish weight did not exceed $3 \%$. Tags were implanted using the shieldedneedle technique (Ross and Kleiner 1982). Fish were held in an oxygenated tank and were anesthetized one at a time. After fish were anesthetized, length and weight were recorded, a scale sample was collected from the side of the fish anterior to the dorsal fin and above the lateral line, and a fin clip was removed from the anal fin. Fish were placed on a v-shaped padded board, and anesthetic was pumped over the gills during surgery. A weight dependent dose ( $1 \mu \mathrm{g}$ of Ocytetracycline per $2 \mathrm{~g}$ of fish body weight) of antibiotic was injected into the incision prior to suturing. Incisions were closed with 34 interrupted sutures. Post-surgery, fish were immediately transferred to an oxygenated, river waterfilled cooler for approximately 20 minutes. Once equilibrium was restored, fish were placed in flowthrough recovery tank for approximately 30 minutes and then returned to slow- water habitat near the tag site.

\section{Fish Tracking}

Tracking was conducted in March and April by cross country skiing along the river to identify when fish began to move. Once movement was detected, approximately $500 \mathrm{~km}$ of stream were scanned weekly to detect fish from May through October, 2008. Tracking occurred via raft, hiking, vehicle, and airplane, and three stationary radio antennae recorded the presence of tagged fish passing within $1 \mathrm{~km}$ of the antenna (located at Jackson Lake Dam, Buffalo Fork, and Moose Junction). The mainstem of the Snake River was monitored from Jackson Lake Dam to Palisades Reservoir. Tracking occurred weekly in the following tributaries: Christian Creek, Spring Creek (near Jackson Lake Dam), Pacific Creek, Buffalo Fork, Spread Creek up to the diversion dam, Blacktail Ponds, Ditch Creek, the Gros Ventre River up to Upper Slide Lake, Three Channel Spring Creek, the Hoback River, Cowboy Cabin Creek, Upper Bar BC spring creeks, Cottonwood Creek (near Moose Junction), Flat Creek, and Fish Creek. Monitoring occurred every two weeks in Bar BC Spring Creek, Cache Creek, and Fall Creek. Tags were relocated via airplane during June and July in: Mosquito Creek, Trail Creek, Taylor Creek, Cottonwood Creek (near the confluence of Fish Creek), the Gros Ventre River and tributaries above Upper Slide Lake, tributaries to Pacific Creek, tributaries to Buffalo Fork, tributaries to the Hoback River, the Grey's River, and tributaries to Cottonwood Creek (near Moose Junction).

Spawning locations were typically defined as the most advanced point (upstream or downstream) that a fish reached on a spawning migration before returning to the pre-spawning location (or a previously unoccupied location). In some cases, spawning fish were observed (e.g., in clear spring creeks) and those redd sites were georeferenced.

\section{RESULTS \& DISCUSSION}

\section{Fish Capture and Tagging}

A total of 49 cutthroat trout were implanted with radio tags. Fish were captured in the Snake River between Jackson Lake Dam and Schwabacher Landing. Between Jackson Lake Dam and the confluence of Pacific Creek, 5 fish (429-472 mm total length, TL) were tagged, 24 fish (332-493 mm TL) were tagged between Pacific Creek and Deadman's Bar boat launch, and 20 fish (365-477 $\mathrm{mm}$ TL) were tagged between Deadman's Bar boat launch and Schwabacher Landing. All fish recovered from surgery and were released in slow water near the point of tagging.

\section{Radio Tracking}

In our initial tracking effort 2 weeks following surgery (November 1, 2007), 36 of 49 fish were relocated (within $1 \mathrm{~m}$ ) and were alive. For these 36 fish, status was determined by either observing the fish swimming or because subsequent relocations demonstrated upstream or lateral movement. It was not possible to determine the condition of the nine other fish that were detected. The location of the remaining four fish is unknown because they were never detected following tagging. The distribution of fish during this relocation event suggests that fish had begun to redistribute into the habitats that were occupied prior to tagging. 


\section{Spawning Locations}

Of 49 tagged Snake River finespotted cutthroat trout, 22 exhibited distinct spawning migrations. Spawning activity of radio-tagged trout was observed in spring creeks $(\mathrm{n}=7)$, tributaries $(\mathrm{n}=10)$, and side channels or mainstem of the Snake River ( $n=5$; Figure 2). This finding is especially significant because cutthroat trout spawning had not previously been observed in the mainstem or side channels of the Snake River. In July, a radio-tagged trout was killed by an angler in the Greys River, a location outside of our search radius. After that encounter, our search radius was expanded to include the Greys River and the Salt River, but no trout were detected. It is possible that spawners entered those systems before scanning began.
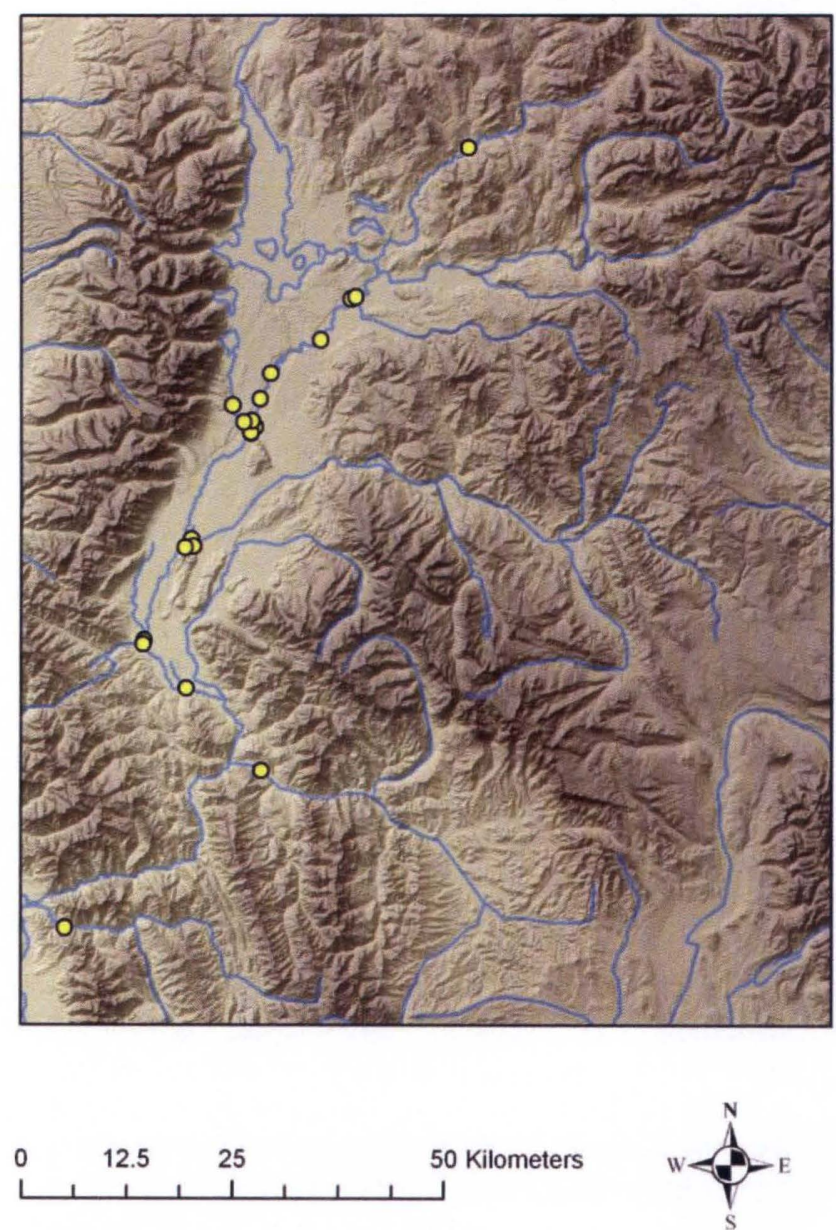

Figure 2. Spawning locations of 22 radio-tagged cutthroat trout (of 49 originally tagged). Fish were initially tagged in 2007 and monitored through the 2008 spawning season.
Cutthroat trout exhibited a great range in spawning migration date and distance moved. The earliest spawning migration was initiated in April, and the last migration was initiated at the end of July, but the majority of spawning occurred in two time periods: June 14-19 and July 5-9 (Figure 3). Migration distance from tag location to spawning location ranged from 0 $110 \mathrm{~km}$. However, the majority of Snake River finespotted cutthroat trout moved 30-40 km (Figure 4). Expanded research on these spawning patterns in 2009 will clarify if this pattern reflects a unique attribute to the Snake River finespotted cutthroat trout life history, or whether it was an artifact of sample size.

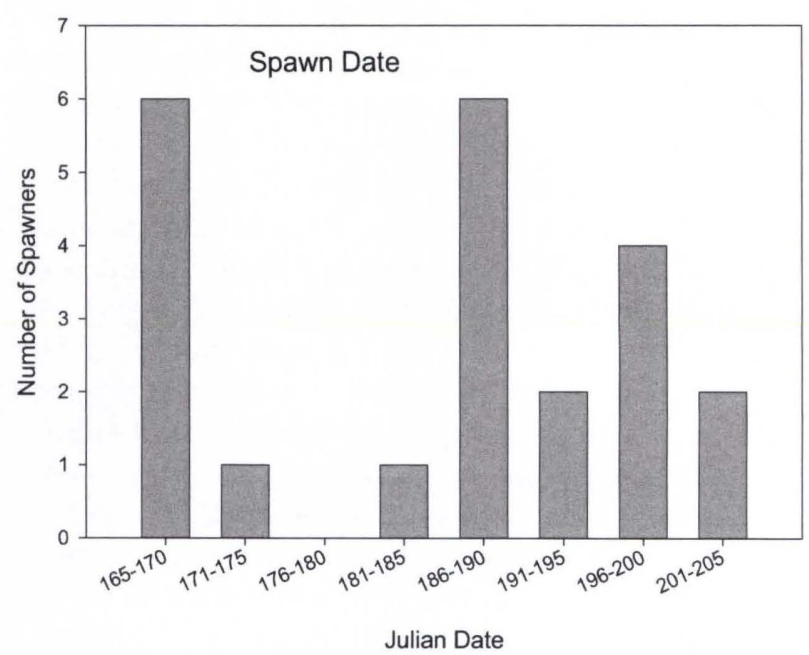

Figure 3. Approximate date of spawning (accumulated in 5day increments) for 22 radio-tagged Snake River finespotted cutthroat trout, based on weekly monitoring May-August 2008.

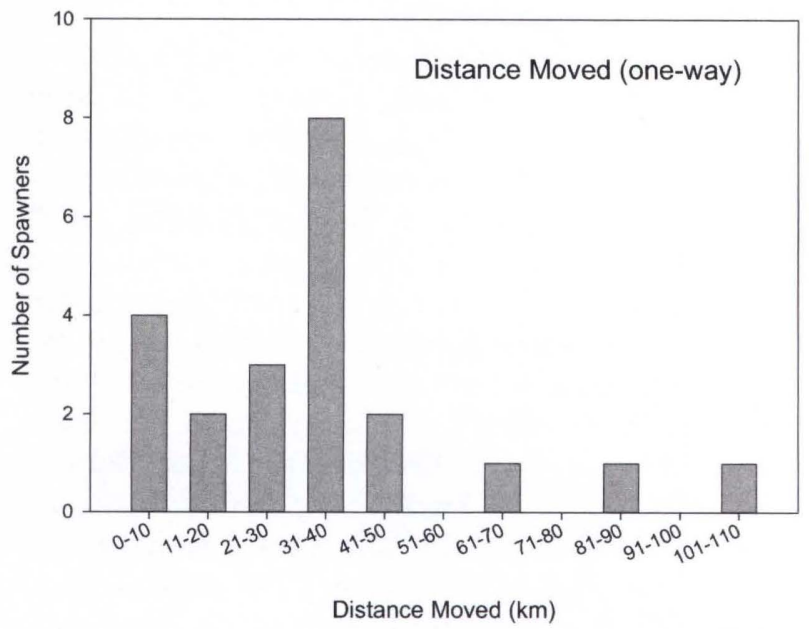

Figure 4. Distance $(\mathrm{km})$ between initial tagging location and spawning location for 22 Snake River finespotted cutthroat trout in the Snake River and tributaries, May-August 2008. 
Irrespective of spawn location, Snake River finespotted cutthroat trout were located in spawning areas for an average of 3 weeks. After departure from spawning areas, most of the trout rapidly returned to pre-spawning locations. Based on a lack of movement or slow downstream movement following spawning, it appears that some trout died either during or after spawning.

Given the small sample size of tagged trout in 2008 , and the great variation among spawn timing and locations observed, it was not possible to detect strong relationships between either the timing or location of spawning and the size of fish or the initial tag location. However, as part of the larger overall project, the number of Snake River cutthroat trout implanted with radio tags increased substantially in $2008(\mathrm{n}=199)$. This larger sample size should increase the probability of detecting factors that affect the timing and location of cutthroat trout spawning in 2009.

This study provided new insights into the life history of Snake River finespotted cutthroat trout. Two life-history types were observed. Fluvial cutthroat trout spawned in the mainstem and side channels of the Snake River, and fluvial-adfluvial fish spawned in spring creeks or tributaries to the Snake River. Although lacustrine-adfluvial and allucustrine lifehistory types are also found in systems that include large lakes (Varley and Gresswell 1988), the Jackson Lake and Palisades dams have fragmented the system and restricted reproductive migrations in this portion of the Snake River watershed. Differences in estimated date of spawning and migration distance were similar for the two life-history types. Fluvial fish $(n=5)$ migrated 1-32 km from tag location to spawning location and spawned between June 16 and July 17 . Fluvial-adfluvial fish $(\mathrm{n}=17)$ moved 4-105 km from tag location to spawning location and spawned between June 14 and July 21.

Irrespective of sample size issues, it is apparent that Snake River finespotted cutthroat trout move extensively throughout the Snake River watershed. It has been suggested that life-history variability is directly related to population persistence and resilience (Den Boer 1968, Warren and Liss 1980, Stearns 1989) due to spreading of extinction risk and temporal and spatial differences in fitness among lifehistory strategies (Gross 1991, Sibly 1991, Northcote 1992). This may be true for small-scale threats to persistence, however, as the balance of disturbance events (stochastic or anthropogenic) shifts in scale from local (e.g., fire or flood) to regional (e.g., dam construction or climate change), more adaptive management will be required to maintain the stream connectivity and habitat conditions to which Snake River finespotted cutthroat trout are adapted.

\section{LITERATURE}

Benda, L., N.L. Poff, D. Miller, T. Dunne, G. Reeves, G. Pess and M. Pollock. 2004. The network dynamics hypothesis: how channel networks structure riverine habitats. BioScience 54:413427.

den Boer, P.J. 1968. Spreading of risk and stabilization of animal numbers. Acta Biotheor. 18:165-194

Gross, M.R. 1991. Salmon breeding behavior and life history evolution in changing environments. Ecology 72(4):1180-1186.

Harig, A.L. and K.D. Fausch. 2002. Minimum habitat requirements for establishing translocated cutthroat trout populations. Ecological Applications 12: 535-551.

Kiefling, J.W. 1978. Studies on the ecology of the Snake River cutthroat trout. Fisheries Technical Bulletin No.3, Wyoming Game and Fish Department, Cheyenne, Wyoming.

Loudenslager, E.J. and R.M. Kitchin. 1979. Genetic similarity of two forms of cutthroat trout, Salmo clarki, in Wyoming. Copeia 1979:673678.

Montgomery, D.R. 1999. Process domains and the river continuum. Journal of the American Water Resources Association 35:397-410.

Northcote, R.G. 1992. Migration and residency in stream salmonids - some ecological considerations and evolutionary consequences. Nordic Journal of Freshwater Research 67:517.

Novak M.A., J.L. Kershner and K.E. Mock. 2005. Molecular genetic investigation of Yellowstone cutthroat trout and finespotted Snake River cutthroat trout. Wyoming Game and Fish Department report \# 165/04.

Pearsons, T.N., H.W. Li and G.A. Lamberti. 1992. Influence of habitat complexity on resistance to flooding and resilience of stream fish assemblages. Transactions of the American Fisheries Society 121:427-436. 
Ross, M.J. and C.F. Kleiner. 1982. Shielded-needle technique for surgically implanting radiofrequency transmitters in fish. Progressive Fish Culturist 44(1):41-43.

Sibly, R.M. 1991. The life-history approach to physical ecology. Functional Ecology 5:184-191.

Stearns, S.C. 1989. Trade-offs in life history evolution. Functional Ecology 3:259-268.

Torgersen, C.E., D.M. Price, H.W. Li and B.A. McIntosh. 1999. Multiscale thermal refugia and stream habitat associations of Chinook Salmon in Northeast Oregon. Ecological Applications 9:301-319.

Torgersen, C.E., C.V. Baxter, H.W. Li and B.A. McIntosh. 2006. Landscape influences on longitudinal patterns of river fishes: spatially continuous analysis of fish-habitat relationships. American Fisheries Society Symposium 48:473-492.

Torgersen C.E., R.E. Gresswell, D.S. Bateman and K.M. Burnett. 2008. Spatial identification of tributary impacts in river networks. Pages 159 182 In: S.P. Rice, A.G. Roy and B.L. Rhoads (eds). River confluences, tributaries and the fluvial network. Wiley, London.
Vannote, R.L., G.W. Minshall, K.W. Cummins, J.R. Sedell and C.E. Cushing. 1980. The River Continuum Concept. Canadian Journal of Fisheries and Aquatic Sciences 37:130-137.

Varley, J.D. and R.E. Gresswell. 1988. Ecology, status, and management of the Yellowstone cutthroat trout. American Fisheries Society Symposium 4: 13-24.

Ward, J.V. and J.A. Stanford. 1983. The serial discontinuity concept of lotic ecosystems. pages 29-42. In: Fontaine TD , Bartell SM (eds.), Dynamics of Lotic Ecosystems. Ann Arbor Scientific Publishers: Ann Arbor, MI.

Warren C.E. and W.J. Liss. 1980. Adaptation to aquatic environments. Pages 15-40 In: R.T. Lackey, and L. Nielsen, (eds). Fisheries Management. Oxford, UK: Blackwell Scientific Publications. 